\title{
Brief communication: Improved simulation of the present-day Greenland firn layer (1960-2016)
}

\author{
Stefan R. M. Ligtenberg, Peter Kuipers Munneke, Brice P. Y. Noël, and Michiel R. van den Broeke \\ Institute for Marine and Atmospheric research Utrecht (IMAU), Utrecht University, Utrecht, The Netherlands \\ Correspondence: Stefan Ligtenberg (s.r.m.ligtenberg@uu.nl)
}

Received: 18 December 2017 - Discussion started: 9 January 2018

Revised: 25 March 2018 - Accepted: 6 April 2018 - Published: 8 May 2018

\begin{abstract}
By providing pore space for storage or refreezing of meltwater, the Greenland ice sheet firn layer strongly modulates runoff. Correctly representing the firn layer is therefore crucial for Greenland (surface) mass balance studies. Here, we present a simulation of the Greenland firn layer with the firn model IMAU-FDM forced by the latest output of the regional climate model RACMO2, version $2.3 \mathrm{p} 2$. In the percolation zone, much improved agreement is found with firn density and temperature observations. A full simulation of Greenland firn at high temporal (10 days) and spatial (11 km) resolution is available for the period 1960-2016.
\end{abstract}

\section{Introduction}

Since the early 1990s, the Greenland ice sheet (GrIS) has been losing mass (Van den Broeke et al., 2016; McMillan et al., 2016) and is currently one of the largest individual contributors to global sea level rise (Chen et al., 2017). During this period, the partitioning of the mass loss between decreasing surface mass balance (SMB) and increasing ice discharge has shifted from close to 50/50 between 2000 and 2005 to runoff dominating the GrIS mass loss over the last decade (Enderlin et al., 2014; Van den Broeke et al., 2016). It is likely that this trend will continue in a warming climate, making it of vital importance to model the GrIS SMB correctly.

A key process in GrIS SMB is the retention of liquid water input (surface meltwater and rainfall) that mitigates the amount of runoff by either refreezing or storing liquid water in the GrIS firn layer. Recently, some features have been discovered that enhance our understanding of meltwater retention: water is stored year-round in firn aquifers (Forster et al.,
2014; Miller et al., 2017); and partly impermeable ice lenses cause lateral transport of water while the underlying firn column remains unsaturated (Machguth et al., 2016). Currently, about $45 \%$ of the liquid water input is estimated to be retained (Steger et al., 2017a, b).

With the firn densification model IMAU-FDM, Kuipers Munneke et al. (2015) simulate the temporal evolution (1960-2014) of the GrIS firn layer. Using density observations from firn cores to evaluate the simulation, they found that model performance in the interior was good, but that the agreement deteriorated with increasing melt rates. Two possibilities for this mismatch were suggested: (1) a representation of liquid water processes in IMAU-FDM that was too simplistic or (2) errors in the atmospheric forcing from the regional climate model (RACMO2.3, Noël et al., 2015). The availability of an updated atmospheric forcing (RACMO2.3p2, Noël et al., 2017) allows us to investigate the impact of the latter. This RACMO2 update resulted in significantly more accumulation inland and less surface melt icesheet wide, improving agreement with SMB observations in both the accumulation and ablation zone (Noël et al., 2017). Since accumulation and surface melt are defining climate variables for the state of the firn, it is expected that the new atmospheric forcing has a marked effect on the simulated GrIS firn layer. Here, we present the new IMAU-FDM simulation and evaluate it using firn density and temperature observations. 


\section{Methods and Data}

\subsection{IMAU-FDM}

A detailed description of the firn densification model IMAUFDM is available in previous publications (Ligtenberg et al., 2011; Kuipers Munneke et al., 2015; Lundin et al., 2017) and will only be briefly summarized here. IMAU-FDM simulates the time evolution of firn density, temperature, liquid water content, and surface elevation in a 1-D column, forced at the surface by sub-daily (3- or 6-hourly) atmospheric output from the regional climate model RACMO2 (see below). Firn compaction is calculated using the densification equations of Arthern et al. (2010), with region-specific additions for Antarctica (Ligtenberg et al., 2011) and Greenland (Kuipers Munneke et al., 2015). Liquid water from rain or surface melt can percolate into the firn using a tipping-bucket model approach, where it is either refrozen or stored depending on firn temperature and pore space. An equilibrium initial firn column is obtained by looping over the 1960-1979 climate until the entire firn column is fully refreshed (Kuipers Munneke et al., 2015). After this spin-up, the transient simulation run starts. The IMAU-FDM simulations forced with RACMO2.3 (FDM2.3 hereafter) and RACMO2.3p2 (FDM2.3p2 hereafter) cover 1960-2014 and 1960-2016, respectively.

\subsection{RACMO2 forcing}

The atmospheric forcing of IMAU-FDM is provided by the regional climate model RACMO2 (Van Meijgaard et al., 2008), of which output of versions v2.3 and v2.3p2 are used here. Forcing consists of prescribing various SMB components (solid and liquid precipitation, surface and drifting snow sublimation, drifting snow erosion, and surface melt), surface temperature $\left(T_{\mathrm{s}}\right)$, and $10 \mathrm{~m}$ wind speed on the native $11 \mathrm{~km}$ RACMO2 grid. RACMO2.3p2 (Van Wessem et al., 2017; Noël et al., 2017) is the updated version of RACMO2.3 (Noël et al., 2015) and includes several changes: updated glacier outlines, topography and ice albedo fields; tuned cloud scheme parameters that increase precipitation towards the GrIS interior, correcting the underestimation of inland accumulation in RACMO2.3; modified snow properties, i.e. lower soot concentration and smaller grain size of refrozen snow that significantly reduce melt production in the percolation zone. For the firn simulations, the most important changes are that inland precipitation on the GrIS (i.e. accumulation area) increases by $5-10 \%$, whereas surface melt along the margins is significantly reduced, by up to $50 \%$, leading to a higher ice-sheet integrated SMB at $11 \mathrm{~km}$ horizontal resolution. Statistical downscaling to $1 \mathrm{~km}$ resolution provides a better representation of runoff on low-elevation outlet glaciers and in narrow ablation zones. As a result, the downscaled SMB agrees better with in situ and basin-scale SMB observations (Noël et al., 2017). Here, the $11 \mathrm{~km}$ data was used as it is computationally not feasible to use the $1 \mathrm{~km}$ data.

\subsection{Firn observations}

Model output from IMAU-FDM is evaluated using firn density and temperature observations from across the GrIS. Vertical profiles of firn density are compared to 62 firn cores of varying depth $(8-120 \mathrm{~m})$ and with locations distributed over the GrIS, although the drier northeast is slightly underrepresented. See Fig. 2 in Kuipers Munneke et al. (2015) for core names and locations, which cover a wide range of melt and accumulation conditions found on the GrIS. Furthermore, deep-firn temperatures (at $10 \mathrm{~m}$ depth, $T_{10 \mathrm{~m}}$ ) in combination with firn density observations along a transect in western Greenland (Harper et al., 2012; Humphrey et al., 2012) are used to analyse the differences in the percolation zone in more detail. The firn air content (FAC) is used as an integrated measure for the amount of pore space present in a firn column and is defined as the vertically integrated difference of the firn density and the ice density (taken to be $917 \mathrm{~kg} \mathrm{~m}^{-3}$ ). In IMAU-FDM, all simulated firn layers extend to below the depth at which the ice density is reached, resulting in modelled FAC to represent the full firn column.

\section{Results}

Figure 1 shows how FDM2.3p2 generally improves the simulated density profiles, compared to FDM2.3. The firn core locations can be separated into three categories based on the melt-accumulation ratio $\left(R_{\mathrm{MA}}\right)$ : (1) the dry snow zone $\left(R_{\mathrm{MA}}<0.05\right)$, (2) locations that experience moderate melt ( $R_{\mathrm{MA}}$ between $0.05-0.5$ ), and (3) high melt locations $\left(R_{\mathrm{MA}}>0.5\right)$. In the first and third category only small differences are noted; the biggest improvements are found in the second category.

For the dry snow zone (example in Fig. 1b), the higher accumulation rates in RACMO2.3p2 result in slightly higher compaction rates and therefore denser firn in FDM2.3p2. Overall, the agreement with observed FAC in the dry snow zone is slightly worse for FDM2.3p2 $\left(r^{2}=0.98\right.$ and $\mathrm{RMSE}=1.08 \mathrm{~m})$ than for FDM2.3 $\left(r^{2}=0.98\right.$ and RMSE $=0.88 \mathrm{~m}$ ) for all cores combined. This is no surprise, however, as Kuipers Munneke et al. (2015) used the vertical density profiles of locations with $R_{\mathrm{MA}}<0.05$ to introduce a correction factor for the densification equations. For comparison purposes, we chose to not repeat this calibration procedure here, leading to a slight overestimation of density in the dry snow zone.

For locations with moderate melt (Fig. 1c-f), both $r^{2}$ (0.87 to 0.92 ) and RMSE (2.81 to $1.70 \mathrm{~m}$ ) show a significant improvement from FDM2.3 to FDM2.3p2. This is mainly caused by the surface melt reduction in the RACMO2.3p2 forcing, resulting in less meltwater refreezing and therefore 


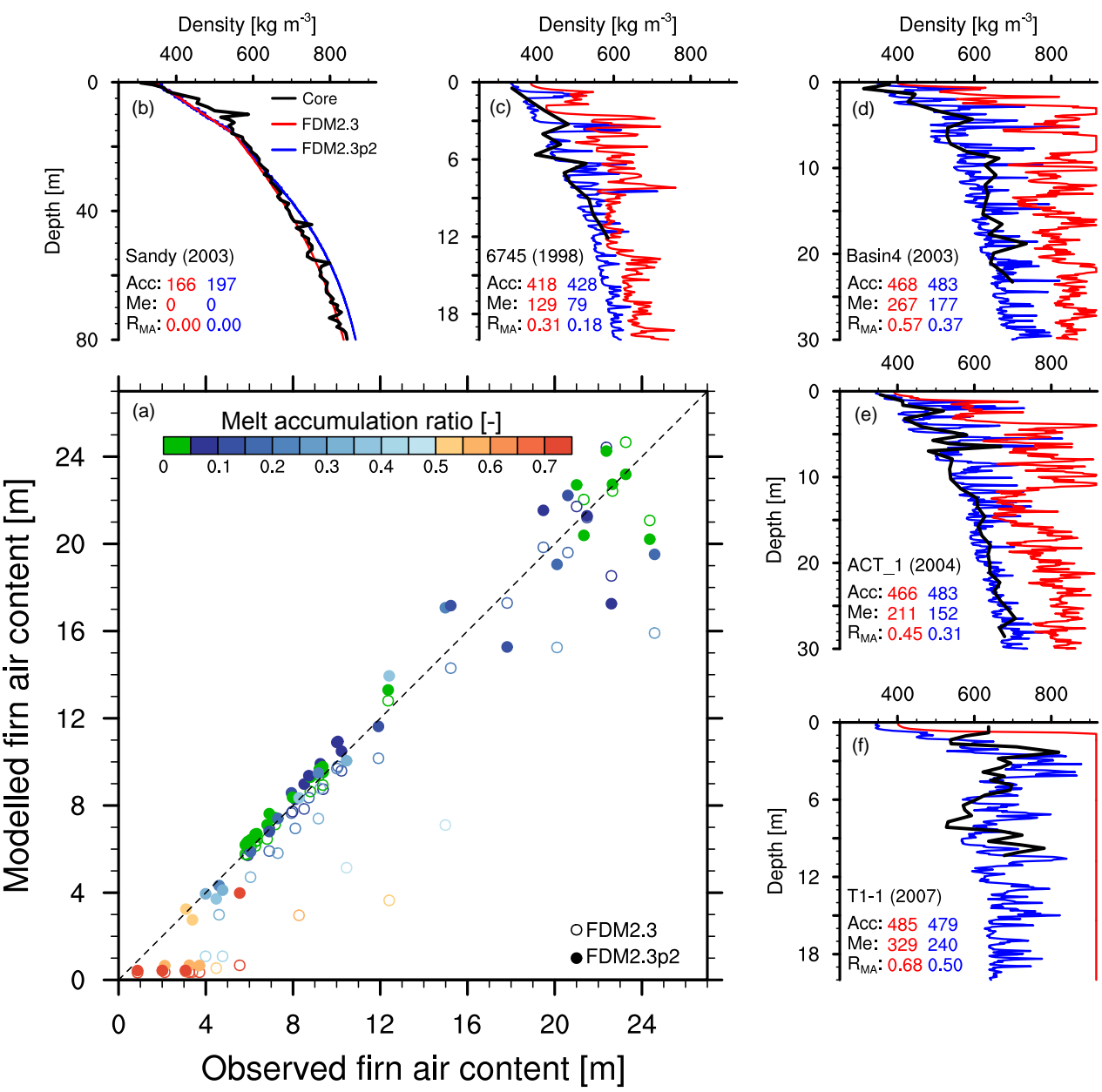

Figure 1. Evaluation of simulated firn density: (a) modelled vs. observed firn air content for FDM2.3 (open circles) and FDM2.3p2 (closed circles) at 62 firn core locations on the GrIS; (b-f) vertical firn density profiles of five selected cores (black), FDM2.3 simulation (red), and FDM2.3p2 simulation (blue). The colours in (a) represent the melt-accumulation ratio of the core location, where green, blue, and red colours indicate the three categories as specified in Sect. 3. In (b-f), the core name and date (black print) is provided, as well as the 1990-2009 average accumulation ("Acc" in mm w.e. $\mathrm{yr}^{-1}$ ), 1990-2009 average surface melt ("Me" in mm w.e. $\mathrm{yr}^{-1}$ ), and the 1990-2009 melt-accumulation ratio ( $R_{\mathrm{MA}}$, unitless) as simulated by RACMO2.3 (red print) and RACMO2.3p2 (blue print). Core names and locations can be found in Fig. 3a.

less dense firn columns. In Fig. 1a, the open circles show the underestimation of FAC in FDM2.3, which is much improved in FDM2.3p2 (closed circles). Another reason for denser firn columns in FDM2.3 is an artefact in the temperature dependent part of the densification equation reported previously by Steger et al. (2017a). In this equation, the firn densification rate is overestimated when the vertically integrated temperature far exceeds the average surface temperature. In Greenland, this led to unrealistically high densification rates in the percolation zone and subsequently too low FAC. In FDM2.3p2, this artefact was solved by replacing the average surface temperature in the densification equation with the temperature of the lowest model layer to account for the additional latent heat of refrozen water.
For the category "locations with $R_{\mathrm{MA}}>0.5$ ", both IMAUFDM simulations underestimate observed FAC (Fig. 1a). The simulated FAC of $\sim 0.5 \mathrm{~m}$ is typical for the model ablation zone at the end of winter, i.e. bare ice covered by a winter snow layer, while the observations suggest that firn of multiple years should be present with FAC varying between 1-4 $\mathrm{m}$. This underestimation in FAC could be caused by remaining biases in atmospheric forcing or processes that are currently not represented in IMAU-FDM (see below). Theory confirms that a firn layer should be present for $R_{\mathrm{MA}}$ as large as $\sim 0.7$ (Pfeffer et al., 1991).

Figures 2 and 3 confirm that the largest differences between FDM2.3 and FDM2.3p2 are found in the percolation zone of the GrIS. Along a transect in the percolation zone of the western GrIS (Harper et al., 2012), it is clear that the firn 

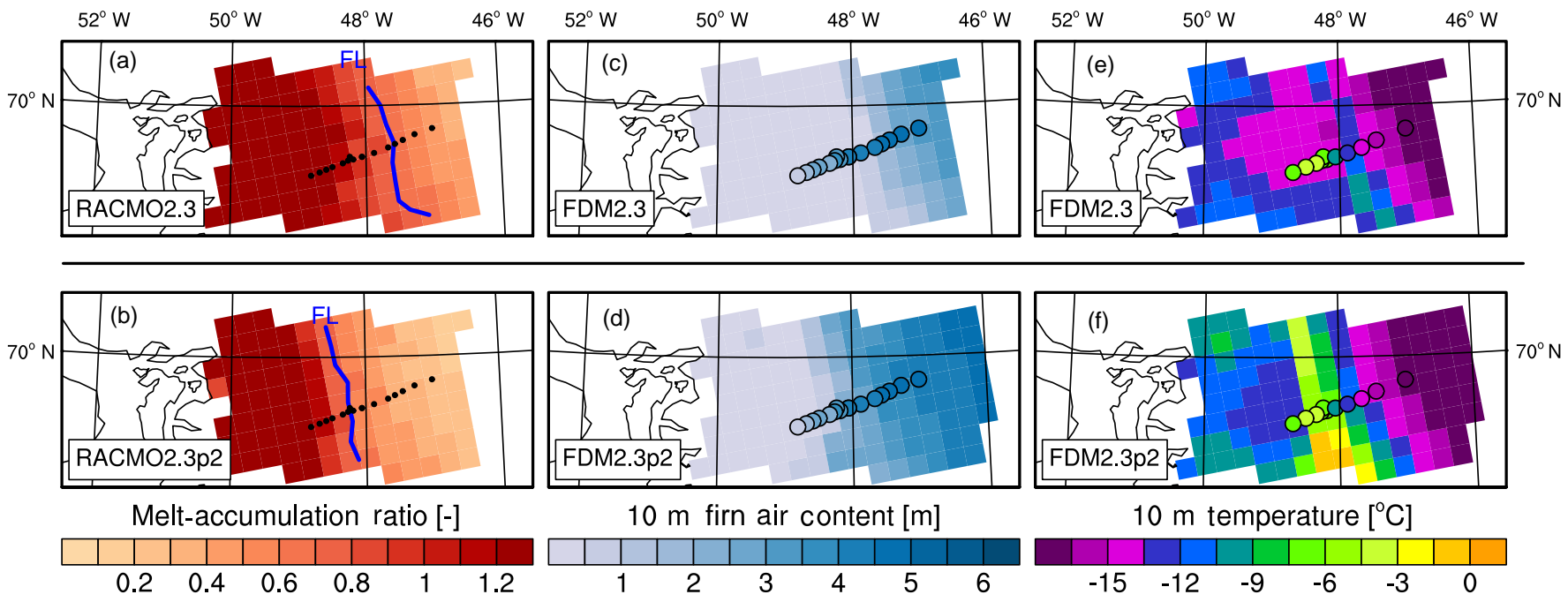
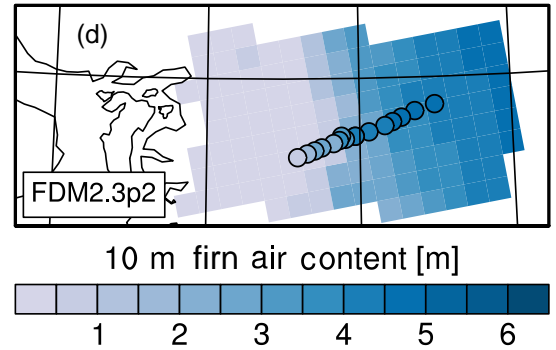

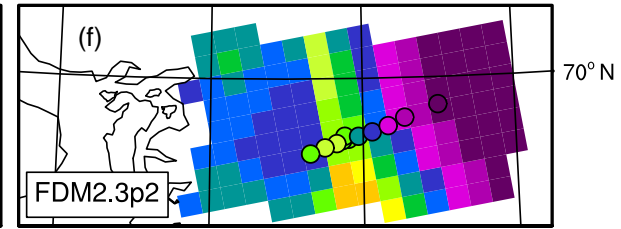

$10 \mathrm{~m}$ temperature $\left[{ }^{\circ} \mathrm{C}\right]$

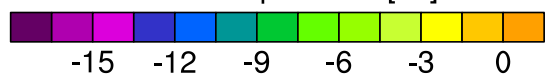

Figure 2. Evaluation of simulated firn air content and $10 \mathrm{~m}$ firn temperature with observations along a transect in the western Greenland (region indicated in Fig. 3b) percolation zone: (a-b) 1990-2009 melt-accumulation ratio $\left(R_{\mathrm{MA}}\right)$ as simulated by RACMO2, (c-d) upper 10 m firn air content as simulated by IMAU-FDM (shaded grid cells) and from firn core observation (circles, Harper et al., 2012); (e-f) average $10 \mathrm{~m}$ firn temperature as simulated by IMAU-FDM (shaded grid cells) and from thermistor string measurements (circles, Humphrey et al., 2012). The figures in (a-b) represent RACMO2.3 and RACMO2.3p2, while (c) and (e) and (d) and (f) represent FDM2.3 and FDM2.3p2, respectively. Blue lines in (a-b) indicate the firn line (FL), chosen to be equal to $R_{\mathrm{MA}}=0.7$. Firn core observations in (c-d) are from July 2007 or May 2008 and the simulated field is an average of these two dates. Both the simulated and observed firn temperatures in (e-f) are averages over 2007-2009.

line (FL, defined as $R_{\mathrm{MA}}=0.7$ ) is simulated further downslope in FDM2.3p2 (Fig. 2a-d). From observed FAC, the FL is located around $48.7^{\circ} \mathrm{W}$, which is almost matched by FDM2.3p2 $\left(\sim 48.3^{\circ} \mathrm{W}\right)$, while FDM2.3 simulates the area where no firn is present up to $\sim 47.5^{\circ} \mathrm{W}(30 \mathrm{~km}$ further inland). Due to the reduction of surface melt in FDM2.3p2, a firn layer is formed at lower elevations. Quantitatively, FAC as simulated by FDM2.3p $2\left(r^{2}=0.71\right.$ and RMSE $\left.=1.64 \mathrm{~m}\right)$ also shows much better agreement than in FDM2.3 $\left(r^{2}=0.40\right.$ and $\mathrm{RMSE}=2.83 \mathrm{~m}$ ).

The remaining discrepancy between the observations and FDM2.3p2, especially for $R_{\mathrm{MA}}>0.5$ (Fig. 1a), is likely caused by how IMAU-FDM treats the vertical transport of liquid water. Currently, a "tipping-bucket" method is used, assuming that water can only run off if both cold content and pore space are unavailable. However, from observations it is found that through heterogeneous percolation (Humphrey et al., 2012) and/or impermeable ice lenses (Machguth et al., 2016), water can run off before all cold content or pore space is used.

Firn temperature is another useful metric to evaluate the performance of IMAU-FDM, especially in locations with substantial surface melt. The amount and depth of refreezing to a large extent determines how much heat is stored in the firn column, i.e. how much $T_{10 \mathrm{~m}}$ deviates from $T_{\mathrm{s}}$. FDM2.3p $2\left(r^{2}=0.39\right.$ and $\left.\mathrm{RMSE}=3.55^{\circ} \mathrm{C}\right)$ shows much improved agreement over FDM2.3 $\left(r^{2}=0.01\right.$ and $\mathrm{RMSE}=6.57^{\circ} \mathrm{C}$ ) for observed $T_{10 \mathrm{~m}}$ (Fig. 2e-f). For the eastern firn cores, realistic firn columns are simulated by both FDM2.3 and FDM2.3p2 with similar deep-firn temperatures as observed. Further west, FDM2.3 simulates lower temperatures than observed, indicating the absence of a firn layer that can store the heat released by refreezing. In FDM2.3p2, a band of higher firn temperatures (around $-4{ }^{\circ} \mathrm{C}$ ) is simulated upslope of the FL, in good agreement with observed temperatures.

When the differences between FDM2.3 and FDM2.3p2 across the entire GrIS are considered (Fig. 3), a clear pattern emerges. The largest differences in both FAC and $T_{10 \mathrm{~m}}$ are located in the percolation zone of the GrIS and are dominated by the decrease in meltwater refreezing. This results in a FAC increase of 5-15 $\mathrm{m}$ and a downslope migration of the $T_{10 \mathrm{~m}}$-band of high temperatures. In the higher elevation regions of the percolation zone, $T_{10 \mathrm{~m}}$ dropped by $2-4^{\circ} \mathrm{C}$ due to the decrease in surface melt and subsequent refreezing and latent heat release, while in the lower percolation zone the presence of a simulated firn layer in FDM2.3p2 results in much higher $T_{10 \mathrm{~m}}$. The largest differences are found in southeast Greenland, where the influence of the previously mentioned temperature artefact in the densification equation is also significant as the firn is close to freezing in these firnaquifer areas. Solving this issue resulted in lower densification rates and therefore thicker firn layers (i.e. high FAC) that are able to store the liquid water year-round as deep firn temperatures are at the freezing point (Fig. 3e). The extent of the firn aquifer is therefore greatly improved in FDM2.3p2 

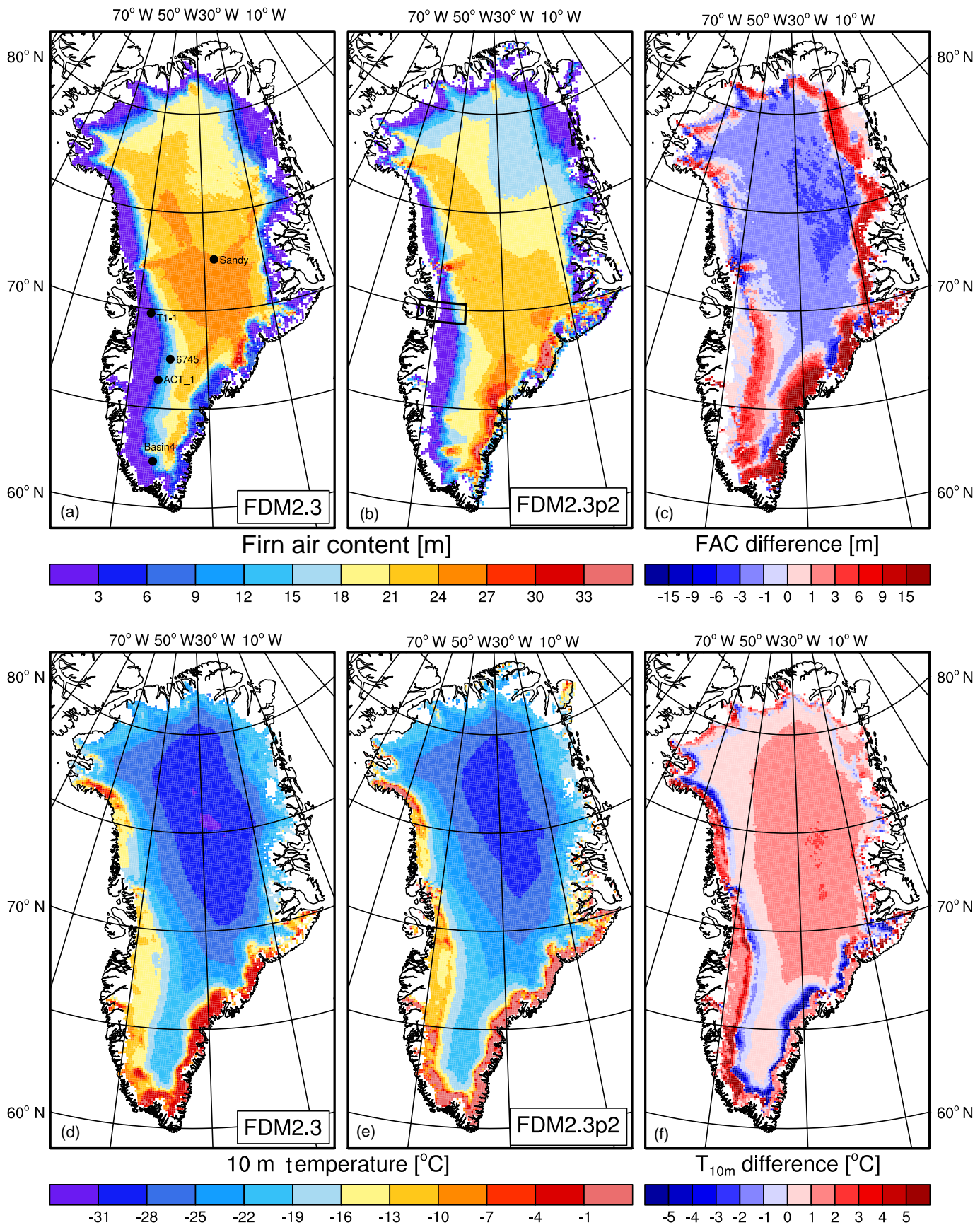

Figure 3. Firn air content (FAC) and $10 \mathrm{~m}$ temperature $\left(T_{10 \mathrm{~m}}\right)$ as simulated by the IMAU-FDM: (a) FAC as simulated by FDM2.3; (b) FAC as simulated by FDM2.3p2; (c) the difference in FAC (FDM2.3p2 minus FDM2.3); panels (d-f) are similar to panels (a-c) only for $T_{10} \mathrm{~m}$ instead of FAC. Locations in (a) indicate the cores used in Fig. 1b-f, while the box in (b) indicates the region used in Fig. 2.

(not shown), compared to the results presented in Steger et al. (2017a).

In the ice sheet interior, the differences between FDM2.3 and FDM2.3p2 are a direct consequence of the atmospheric forcing: the increased accumulation results in faster densification and 2-3 m lower FAC, while the $T_{10 \mathrm{~m}}$ increase is almost identical in magnitude and spatial pattern to the increase in $T_{2 \mathrm{~m}}$ from RACMO2.3 to RACMO2.3p2 (not shown). The lowest regions of the GrIS show no differences in FAC, as it is an ablation area in both model simulations. However, for $T_{10 \mathrm{~m}}, \mathrm{FDM} 2.3 \mathrm{p} 2$ simulates $1-2{ }^{\circ} \mathrm{C}$ higher temperatures in the ablation zone, caused by a shorter presence of bare ice at the surface (i.e. increased insulating effect of a snow/firn layer). Over 1990-2009, FDM2.3p2 simulates 
20 days $\mathrm{yr}^{-1}(25 \%)$ less bare-ice exposure than FDM2.3. Averaged over the entire GrIS (using only grid cells that are present in both FDM2.3 and FDM2.3p2), the $T_{10 \mathrm{~m}}$ difference is $+0.94{ }^{\circ} \mathrm{C}$ and the FAC difference is $+1.13 \mathrm{~m}(8 \%)$. The latter corresponds to a volume difference of roughly $2000 \mathrm{~km}^{3}$ and is equivalent to 11 years of meltwater storage at the 1960-1990 refreezing rate.

\section{Conclusions}

It is shown that the firn layer on the GrIS is highly sensitive to the forcing climate, mainly surface melt and accumulation. Improved atmospheric forcing (increased inland snowfall and decreased surface melt) from RACMO2, version 2.3p2, leads to significant improvements in simulated FAC and $T_{10 \mathrm{~m}}$ in the percolation zone. In the interior dry snow zone and the ablation zone no large changes are found. The results suggest that the Greenland firn layer contains more pore space than previously thought, which has important implications for the liquid water retention capacity of the GrIS. A higher buffering capacity to retain liquid water by either refreezing or storage is especially important if present-day firn conditions are used as starting point for future simulations, as it will delay and reduce the increase in runoff in a future warming climate. Data from the full simulation of Greenland firn density, temperature, and liquid water content at high temporal (10 days) and spatial resolution $(11 \mathrm{~km})$ are available for the period 1960-2016.

Data availability. Modelled time series of firn air content and $10 \mathrm{~m}$ firn temperature are available on Pangaea, https://doi.org/10.1594/PANGAEA.884617. All other IMAU-FDM output is available from the authors without conditions.

Competing interests. The authors declare that there are no competing interests.

Acknowledgements. All authors acknowledge support of the Polar Program of the Netherlands Organisation for Scientific Research (NWO) and the Netherlands Earth System Science Centre (NESSC). Stefan Ligtenberg is supported by an NWO-ALW Veni grant, number 863.15.023.

Edited by: Martin Schneebeli

Reviewed by: Christopher Max Stevens and one anonymous referee

\section{References}

Arthern, R. J., Vaughan, D. G., Rankin, A. M., Mulvaney, R., and Thomas, E. R.: In situ measurements of Antarctic snow compaction compared with predictions of models, J. Geophys. Res., 115, F03011, https://doi.org/10.1029/2009JF001306, 2010.
Chen, X., Zhang, X., Church, J. A., Watson, C. S., King, M. A., Monselesan, D., Legresy, B., and Harig, C.: The increasing rate of global mean sea-level rise during 1993-2014, Nat. Clim. Change, 7, 492-495, https://doi.org/10.1038/nclimate3325, 2017.

Enderlin, E. M., Howat, I. M., Jeong, S., Noh, M.-J., van Angelen, J. H., and van den Broeke, M. R.: An improved mass budget for the Greenland ice sheet, Geophys. Res. Lett., 41, 866-872, https://doi.org/10.1002/2013GL059010, 2014.

Forster, R. R., Box, J. E., van den Broeke, M. R., Miège, C., Burgess, E. W., van Angelen, J. H., Lenaerts, J. T. M., Koenig, L. S., Paden, J., Lewis, C., Gogineni, S. P., Leuschen, C., and McConnell, J. R.: Extensive liquid meltwater storage in firn within the Greenland ice sheet, Nat. Geosci., 7, 95-98, https://doi.org/10.1038/ngeo2043, 2014.

Harper, J., Humphrey, N., Pfeffer, W. T., Brown, J., and Fettweis, X.: Greenland ice-sheet contribution to sea-level rise buffered by meltwater storage in firn, Nature, 491, 240-243, https://doi.org/10.1038/nature11566, 2012.

Humphrey, N. F., Harper, J. T., and Pfeffer, W. T.: Thermal tracking of meltwater retention in Greenland's accumulation area, J. Geophys. Res., 117, F01010, https://doi.org/10.1029/2011JF002083, 2012.

Kuipers Munneke, P., Ligtenberg, S. R. M., Noël, B. P. Y., Howat, I. M., Box, J. E., Mosley-Thompson, E., McConnell, J. R., Steffen, K., Harper, J. T., Das, S. B., and van den Broeke, M. R.: Elevation change of the Greenland Ice Sheet due to surface mass balance and firn processes, 1960-2014, The Cryosphere, 9, 2009-2025, https://doi.org/10.5194/tc-9-2009-2015, 2015.

Ligtenberg, S. R. M., Helsen, M. M., and van den Broeke, M. R.: An improved semi-empirical model for the densification of Antarctic firn, The Cryosphere, 5, 809-819, https://doi.org/10.5194/tc-5809-2011, 2011.

Ligtenberg, S. R. M., Kuipers Munneke, P., Noel, B. P. Y., and van den Broeke, M. R.: Modelled firn air content and $10 \mathrm{~m}$ firn temperature for the Greenland ice sheet (1960-2016) in NetCDF format, Pangaea, https://doi.org/10.1594/PANGAEA.884617, 2018.

Lundin, J. M. D., Stevens, C. M., Arthern, R., Buizert, C., Orsi, A., Ligtenberg, S. R. M., Simonsen, S. B., Cummings, E., Essery, R., Leahy, W., Harris, P., Helsen, M. M., and Waddington, E. D.: Firn Model Intercomparison Experiment (FirnMICE), J. Glaciol., 63, 401-422, https://doi.org/10.1017/jog.2016.114, 2017.

Machguth, H., MacFerrin, M., van As, D., Box, J. E., Charalampidis, C., Colgan, W., Fausto, R. S., Meijer, H. A. J., Mosley-Thompson, E., and van de Wal, R. S. W.: Greenland meltwater storage in firn limited by near-surface ice formation, Nat. Clim. Change, 6, 390-393, https://doi.org/10.1038/nclimate2899, 2016.

McMillan, M., Leeson, A., Shepherd, A., Briggs, K., Armitage, T. W. K., Hogg, A., P. Kuipers Munneke, van den Broeke, M. R., Noël, B., van de Berg, W. J., Ligtenberg, S. R. M., Horwath, M., Groh, A., Muir, A., and Gilbert, L.: A high-resolution record of Greenland mass balance, Geophys. Res. Lett., 43, 7002-7010, https://doi.org/10.1002/2016GL069666, 2016.

Miller, O. L., Solomon, D. K., Miège, C., Koenig, L. S., Forster, R. R., Montgomery, L. N., Schmerr, N., Ligtenberg, S. R. M., Legchenko, A., and Brucker, L.: Hydraulic Conductivity of a Firn Aquifer in Southeast Greenland, Frontiers Earth Sci., 5, 38, https://doi.org/10.3389/feart.2017.00038, 2017. 
Noël, B., van de Berg, W. J., van Meijgaard, E., Kuipers Munneke, P., van de Wal, R. S. W., and van den Broeke, M. R.: Evaluation of the updated regional climate model RACMO2.3: summer snowfall impact on the Greenland Ice Sheet, The Cryosphere, 9, 1831-1844, https://doi.org/10.5194/tc-9-1831-2015, 2015.

Noël, B., van de Berg, W. J., van Wessem, J. M., van Meijgaard, E., van As, D., Lenaerts, J. T. M., Lhermitte, S., Kuipers Munneke, P., Smeets, C. J. P. P., van Ulft, L. H., van de Wal, R. S. W., and van den Broeke, M. R.: Modelling the climate and surface mass balance of polar ice sheets using RACMO2 Part 1: Greenland (1958-2016), The Cryosphere, 12, 811-831, https://doi.org/10.5194/tc-12-811-2018, 2018.

Pfeffer, W. T., Meier, M. F., and Illangasekare, T. H.: Retention of Greenland Runoff by Refreezing: Implications for Projected Future Sea Level Change, J. Geophys. Res., 96, 22117-22124, https://doi.org/10.1029/91JC02502, 1991.

Steger, C. R., H. Reijmer, C., van den Broeke, M. R., Wever, N., Forster, R. R., Koenig, L. S., Kuipers Munneke, P., Lehning, M., Lhermitte, S., Ligtenberg, S. R. M., Miège, C., and Noël, B. P. Y.: Firn Meltwater Retention on the Greenland Ice Sheet: A Model Comparison, Frontiers Earth Sci., 5, 3, https://doi.org/10.3389/feart.2017.00003, 2017a.

Steger, C. R., Reijmer, C. H., and van den Broeke, M. R.: The modelled liquid water balance of the Greenland Ice Sheet, The Cryosphere, 11, 2507-2526, https://doi.org/10.5194/tc-11-25072017, 2017b. van den Broeke, M. R., Enderlin, E. M., Howat, I. M., Kuipers Munneke, P., Noël, B. P. Y., van de Berg, W. J., van Meijgaard, E., and Wouters, B.: On the recent contribution of the Greenland ice sheet to sea level change, The Cryosphere, 10, 1933-1946, https://doi.org/10.5194/tc-10-1933-2016, 2016.

Van Meijgaard, E., van Ulft, L. H., van de Berg, W. J., Bosveld, F. C., van den Hurk, B. J. J. M., Lenderink, G., and Siebesma, A. P.: The KNMI regional atmospheric climate model RACMO version 2.1, Royal Netherlands Meteorological Institute, De Bilt, The Netherlands, 2008.

van Wessem, J. M., van de Berg, W. J., Noël, B. P. Y., van Meijgaard, E., Birnbaum, G., Jakobs, C. L., Krüger, K., Lenaerts, J. T. M., Lhermitte, S., Ligtenberg, S. R. M., Medley, B., Reijmer, C. H., van Tricht, K., Trusel, L. D., van Ulft, L. H., Wouters, B., Wuite, J., and van den Broeke, M. R.: Modelling the climate and surface mass balance of polar ice sheets using RACMO2, part 2: Antarctica (1979-2016), The Cryosphere Discuss., https://doi.org/10.5194/tc-2017-202, in review, 2017. 